\title{
METHODS OF AVAILABLE POTASSIUM ASSESSMENT IN SELECTED SOILS OF KWARA STATE, NIGERIA
}

\author{
${ }^{1 *}$ Affinnih, K. O., ${ }^{2}$ Salawu, I. S. and ${ }^{3}$ ssah, A. S. \\ Department of Agronomy, Faculty of Agriculture, University of llorin, llorin Kwara State, Nigeria \\ Department of Mathematics and Statistics, Abdul Gusau Polytechnic, Gusau, Zafara State, \\ Nigeria \\ Department of Agronomy, Ahmadu, Bello University, Zaria, Kaduna State, Nigeria.
}

\begin{abstract}
Responses to potassium $(K)$ by potted Sorghum (Sorghum bicolor) were determined in soils taken from four Local Government Areas in Kwara State and regressed with K extracted with five laboratory methods. Results showed that without $K$ application, dry-matter yields were relatively high and responses to $15 \mathrm{~kg}, 30 \mathrm{~kg}$ and $60 \mathrm{~kg} \mathrm{~K} \mathrm{ha}^{-1}$ were negative and not significant in the soils derived from basement complex and sandstones. When dry matter yields without $K$ application were less than $9.00 \mathrm{~g} / \mathrm{pot}$, there were no significant responses to $K$ application and responses were significant only when they were more than $9 \%$. Potassium extracted with $\mathrm{N} \mathrm{NH}_{4} \mathrm{OAc} \mathrm{pH} 7.0$ gave the best indication of dry matter yields when $K$ was not applied, with the equation, $Y=$ $0.005 X+3.1902, r=0.1622$. Significant responses were obtained in soil testing with less than 15 $\mathrm{kg} \mathrm{K} \mathrm{ha-1}$ with this method. Furthermore, $\mathrm{K}$ extracted with hot $\mathrm{N} \mathrm{HNO}_{3}$ was almost equal with a higher value in virtually all soils to exchangeable $\mathrm{K}$ extracted with $\mathrm{N} \mathrm{NH}_{4} \mathrm{OAc}$ and could be used in place of this extractant as it also accounts for the replenishable form of $K$ in soil.
\end{abstract}

Keywords: A-value, extractants, $\mathrm{K}$ status, \% K response, Sorghum, uptake

\section{INTRODUCTION}

Soil potassium $\left(\mathrm{K}^{+}\right)$exists in solution, exchangeable, and non-exchangeable forms that are in dynamic equilibrium with each other (Cox et al., 1999). Exchangeable $K$ is widely used for evaluating the soil K status and prediction of crop K requirements (Samaadi, 2006; Krauss, 2003) while in other countries the $\mathrm{K}$ saturation index $(\%)$ is used for the assessment of soil $\mathrm{K}$ status (Mutscher, 1995). However, research has shown that solution and exchangeable $\mathrm{K}^{+}$are replenished by non-exchangeable $\mathrm{K}^{+}$when they are depleted by plant removal or leaching.

Bansal et al. (2002) showed that exchangeable $K$ alone cannot be used as the basis for evaluating $\mathrm{K}$ availability under intensive cropping; as those soils considered sufficient in exchangeable $\mathrm{K}$ were not able to maintain that condition for long under intensive cropping with high yielding varieties. Similarly, Mohammed (2006) observed that complications arise in the use of neutral normal ammonium acetate $\left(\mathrm{NH}_{4} \mathrm{OAc}\right) \mathrm{pH} 7.0$, as some of the non-exchangeable $\mathrm{K}$ was utilized by plants. Thus, it is considered important to study methods of available $\mathrm{K}$ extraction for better understanding of the fertility status of agricultural soils.

The choice of the particular extractant is however decided by establishing a correlation between the amounts extracted and crop growth or yield. In order to make accurate predictions of crop response to potassium, soil test methods should have a high correlation with crop performance (Ekpete, 1972). Also, the economically optimum fertilizer rate, an estimate calculated by fitting a 
regression model with crop yield as the response variable and the amount of applied nutrient as the predictor variable have been used as bench marks for fertilizer needs (National Academy of Sciences - National Research Council, 1961; Stanford, 1973; Vanotti and Bundy, 1994a,b; Rehm et al., 2006).

Dean (1954) obtained available phosphorus values in soils where the yield- of- phosphorus curves fitted the equation $Y=a+b X$ by extrapolating the curves to the $X$-axis. The values approximated the A-values which Fried and Dean (1952) had conceived in the measurement of available soil nutrients (Ekpete, 1972). Dilute mineral acids, exchangeable potassium and potassium extracted with very dilute $\mathrm{CaCl}_{2}$ solution were employed in extracting potassium from the soils used in this study. This knowledge is required for a soil-testing service which is very important in the programme of increasing food production through fertilizer application.

\section{MATERIALS AND METHODS}

\section{Soils}

The soils used were taken from four locations with different cropping histories. The locations were Otte in Asa Local Government Area (LGA), Tsaragi in Edu LGA, Malete in Mooro LGA and Omu Aran in Irepodun LGA of Kwara state (Fig. 1) owing to the farming activities in these areas. The soils were formed on basement complex rocks, which covered fourteen out of the sixteen local government areas of the State except Tsaragi's which formed on sandstone found in two LGAs of Kwara state.

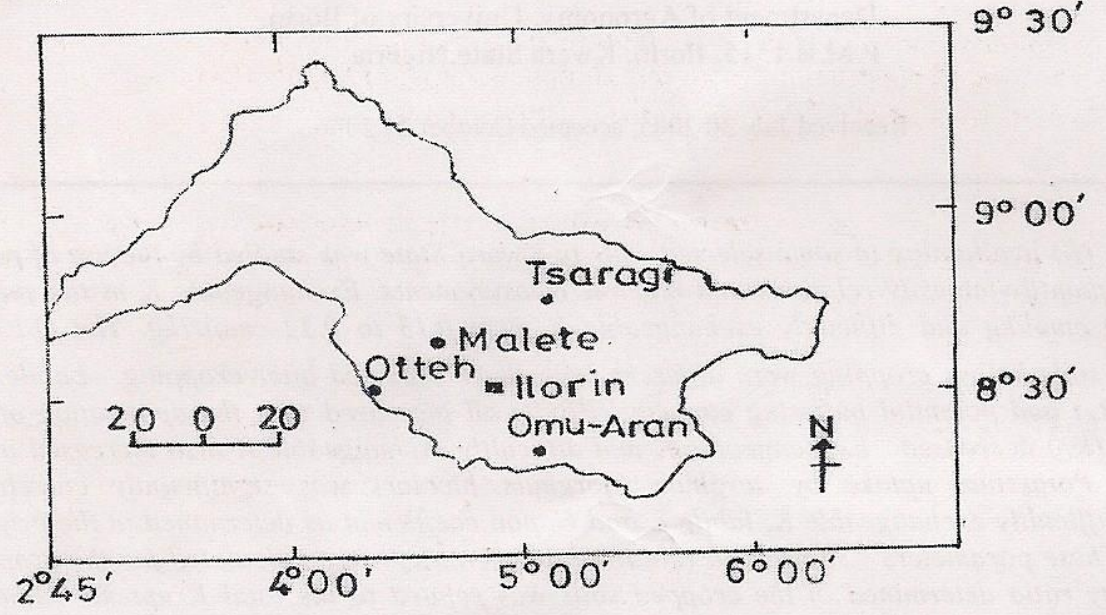

Figure 1: A map of Kwara State showing the sample locations

The surface soils $(0-15 \mathrm{~cm})$ were collected from twenty spots in each location and then bulked. The bulk samples were air-dried, ground and sieved to pass through $2 \mathrm{~mm}$ sieve. Sub samples of the soils were analyzed for physic-chemical characterization. 


\section{Greenhouse study}

$0.75 \mathrm{~kg}$ of sieved soil were weighed and put into plastic pot of about 1 litre capacities. Nutrient solutions containing $0.177 \mathrm{~g}\left(\mathrm{NH}_{4}\right)_{2} \mathrm{HPO}_{4}$ were applied to the soil in each bowl at the rate of 100 and $110 \mathrm{~kg} \mathrm{ha}^{-1}$ of nitrogen $(\mathrm{N})$ and phosphorus $(\mathrm{P})$ respectively. The levels of $\mathrm{K}$ applied were 0 , $15,30,45$ and $60 \mathrm{~kg} \mathrm{ha}^{-1}$. These were applied a week after germination. Three replications were used for each soil. The contents of each bowl were watered to approximately field capacity daily. Five Sorghum bicolor seeds were sown in each bowl, but after germination, they were thinned to two plants per bowl. Harvesting of sorghum tops were carried out after four weeks, dried in the oven at $60^{\circ} \mathrm{C}$ for three days, and then weighed and milled. The ground plant tissues were wet digested with a mixture of $\mathrm{HNO}_{3}$ and $\mathrm{HClO}_{3}$ (Isaac and Kerber, 1971) and $\mathrm{K}$ in the digests determined by flame photometry.

\section{Analytical procedure}

The A-value was determined for each soil by a simple regression analysis of applied potassium rate upon the potassium uptake data and extrapolation of the line to the X-axis (Fig.2). The negative value with the sign changed to positive was regarded as the A-value and represented the amount of soil potassium which was as available as the applied potassium (Fried and Dean, 1952; Ekpete, 1972).

The dry matter yields at each level of $\mathrm{K}$ application were obtained by totaling the cutting weights and the percentage response was obtained as:

$\%$ response at $15 \mathrm{~kg} \mathrm{~K} \mathrm{ha}^{-1}=\frac{\text { Yield at } 15 \mathrm{~kg} \mathrm{~K} \mathrm{ha}^{-1}-\text { Yield without applied } \mathrm{K}}{\text { Yield at } 15 \mathrm{~kg} \mathrm{~K} \mathrm{ha}^{-1}}$


Fig.2. DETERMINATION OF A-VALUE FOR OTTE SOIL

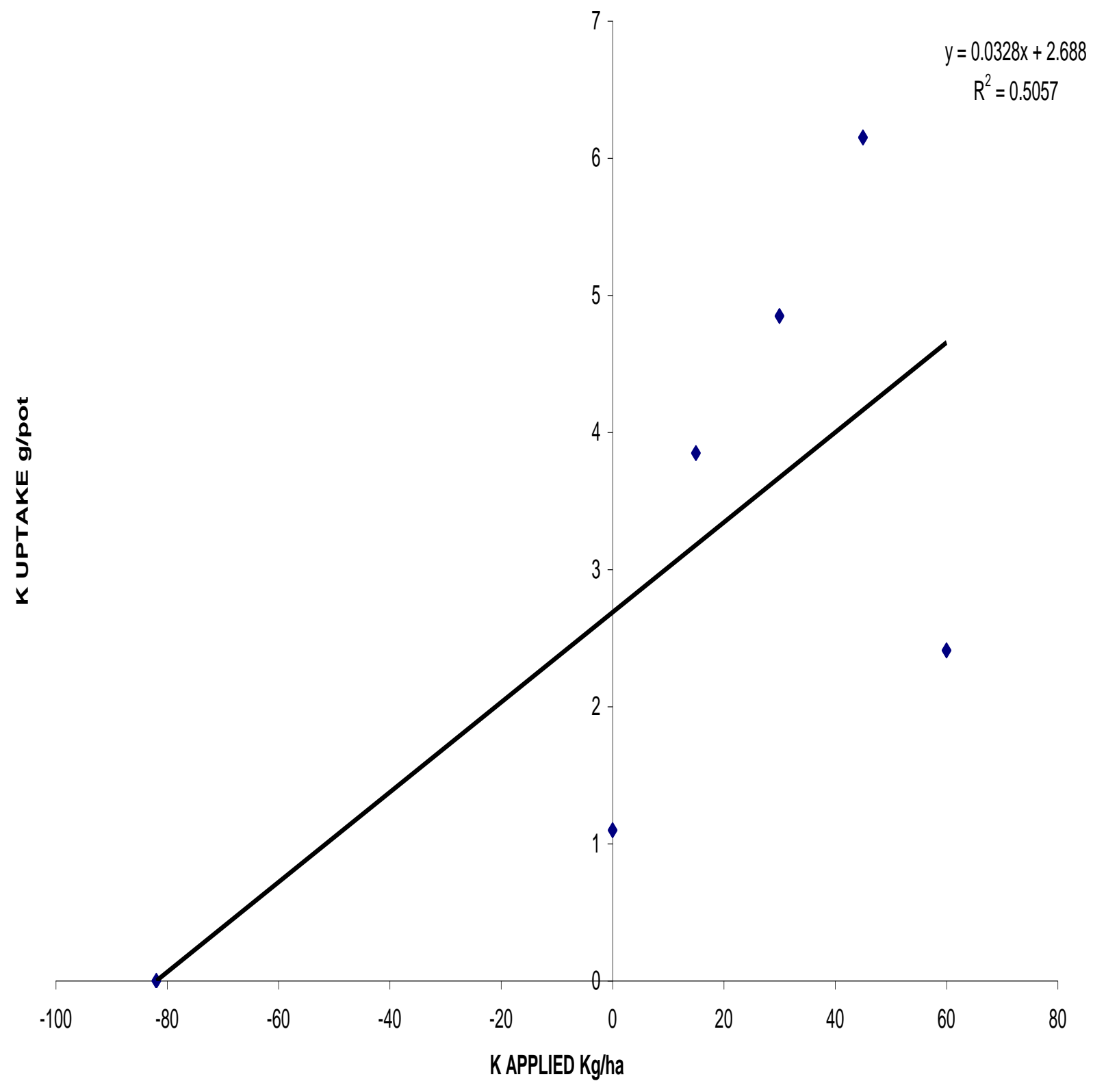




\section{Laboratory methods.}

The laboratory methods which were considered most suitable for the routine evaluation of $\mathrm{K}$ availability indices in the southern Guinea Savanna of Nigeria soils among those tested were:

i. $\quad \mathrm{NH}_{4} \mathrm{OAc} \mathrm{pH} 7.0$

ii. $\quad 0.01 \mathrm{M} \mathrm{CaCl}_{2}$

iii. $\quad \mathrm{Hot} \mathrm{NHNO}_{3}$ (Mohammed, 2006).

Correlation coefficients and regressions were calculated between dry matter yield and percentage response on one hand, and the A-value and data of the five laboratory methods on the other. By analysis of variance, the least significance differences within the data of the dry matter yield, percentage response, A-value and the laboratory methods were calculated.

\section{RESULTS AND DISCUSSION}

Some properties of the soils used for the potted experiment were summarized in Table 1. The soils were generally loamy sand to sandy loam in texture with kaolinite being the dominant mineral (Ogunwale et al., 2002). Their organic matter is low and this is partly attributed to annual burning, a phenomenon which reduces builds up of organic matter. The dry matter yields, responses to potassium application, data by different laboratory methods, for the different soils, and the correlation and regression data are shown in

Table 1, Fig. 3 and Fig. 4

Table 1: Some Physico-chemical Properties of the Soils Studied

\begin{tabular}{llccc} 
Soil variables & Otte & Tsaragi & Malete & Omu Aran \\
\hline $\mathrm{pH}\left(1: 1, \mathrm{H}_{2} \mathrm{O}\right)$ & 6.30 & 6.30 & 5.7 & 4.0 \\
Organic carbon $(\mathrm{g} / \mathrm{kg})$ & 13.6 & 20.3 & 3.6 & 16.8 \\
Gravel content $(\mathrm{g} / \mathrm{kg})$ & 110.6 & 18.1 & 13.8 & 144.5 \\
Clay $(\mathrm{g} / \mathrm{kg})$ & 63.2 & 63.2 & 63.2 & 144.8 \\
Silt $(\mathrm{g} / \mathrm{kg})$ & 152.8 & 152.8 & 152.8 & 200.0 \\
Sand $(\mathrm{g} / \mathrm{kg})$ & 784.0 & 784.0 & 784.0 & 655.2 \\
Total Acidity (cmol/kg) & 0.28 & 0.24 & 0.20 & 0.60 \\
Exchangeable bases (cmol $/ \mathrm{kg})$ & & & & \\
$\mathrm{Ca}$ & 4.00 & 2.40 & 4.00 & 2.00 \\
$\mathrm{Mg}$ & 2.00 & 5.20 & 3.20 & 2.40 \\
$\mathrm{~K}$ & 0.47 & 0.04 & 0.04 & 0.14 \\
$\mathrm{Na}$ & 0.13 & 0.10 & 0.07 & 0.13 \\
${ }^{*} \mathrm{ECEC}$ & 6.88 & 8.01 & 7.47 & 5.27 \\
\hline
\end{tabular}

${ }^{*}$ Effective CEC $=$ TEB + Total Acidity

Without potassium application, all the soils studied produced low dry matter yields below $20 \mathrm{~g} / \mathrm{pot}$ (Ekpete, 1972); average yield for the four soils of Kwara State was $9.53 \mathrm{~g} / \mathrm{pot}$. Among the four soils, dry matter yield was lowest in Malete and highest in Omu-Aran. There were positive significant yield responses to $15 \mathrm{~kg} \mathrm{~K} \mathrm{ha}^{-1}$ in Tsaragi and Omu-Aran soils while the soils of Otte and Malete had high negative significant responses at this $\mathrm{K}$ rate. At $30 \mathrm{~kg} \mathrm{~K} \mathrm{ha}^{-1}$ all soils except Omu-Aran had significant negative responses, although the difference between yields at 15 and 
$30 \mathrm{~kg} \mathrm{~K} \mathrm{ha}^{-1}$ was not significant except in soils taken from Otte and Omu-Aran; this was why the yield at $15 \mathrm{~kg} \mathrm{~K}$ ha-1 $^{-1}$ was used as the maximum in calculating the percentage response.

For A-value and data of the laboratory methods, the potassium status was generally low for Malete soil and high to very high for the other three locations soils. Significant responses occurred when the A-value was below $70 \mathrm{~kg} \mathrm{ha}^{-1}$, total $\mathrm{K}$ was below $53.6 \mathrm{~kg} \mathrm{~K} \mathrm{ha}^{-1}, 0.01 \mathrm{M} \mathrm{CaCl}_{2}-$ $\mathrm{K}$ below $1.38 \mathrm{~kg} \mathrm{ha}^{-1}, 0.5 \mathrm{~N} \mathrm{NaHCO}_{3}-\mathrm{K}$ below 
Fig. 3. Regression of dry matter yields at No-K upon A-value and K extractable with laboratory methods
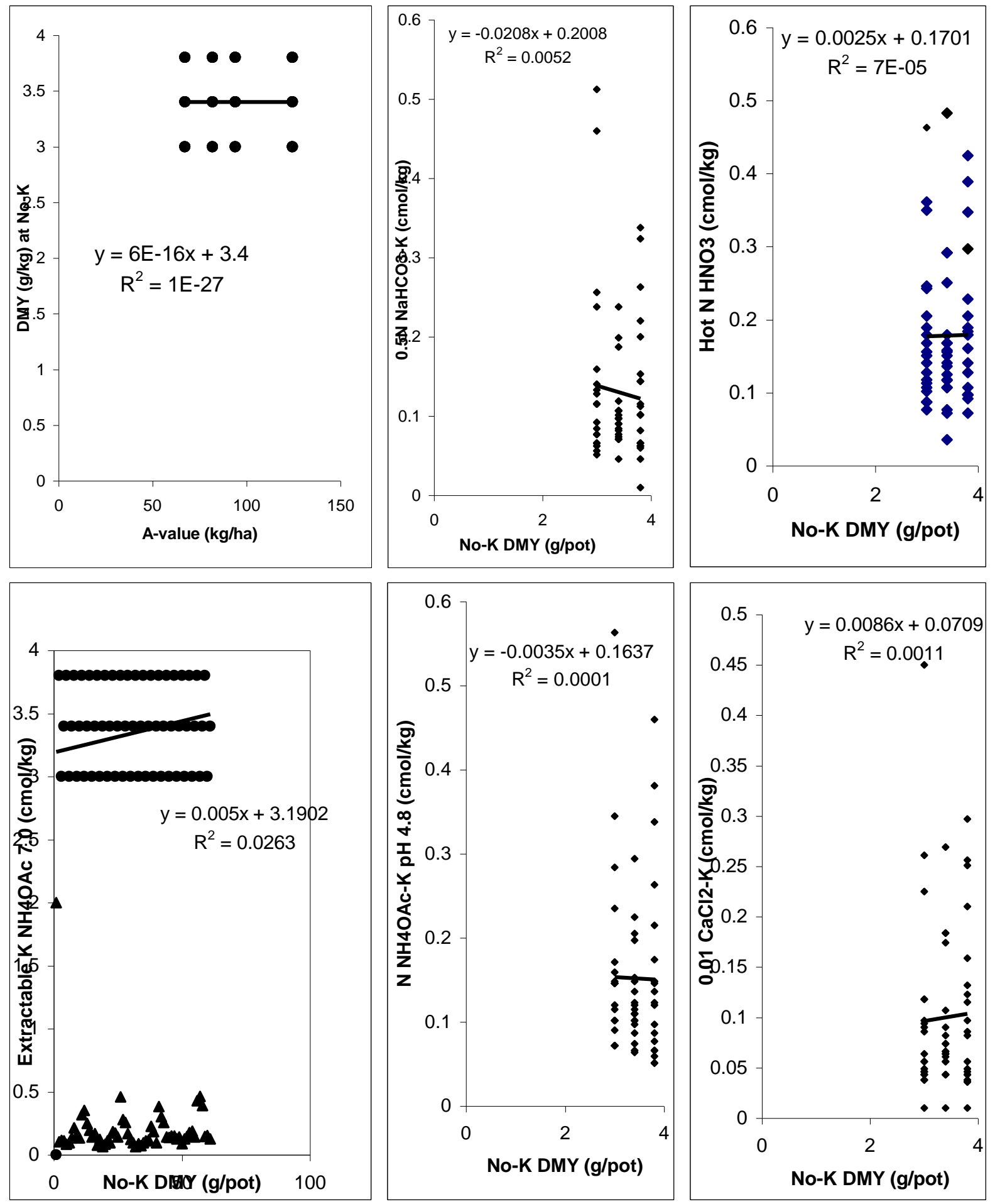
Fig. 4. Regression of \% response upon A-value and K extractable with laboratory methods.
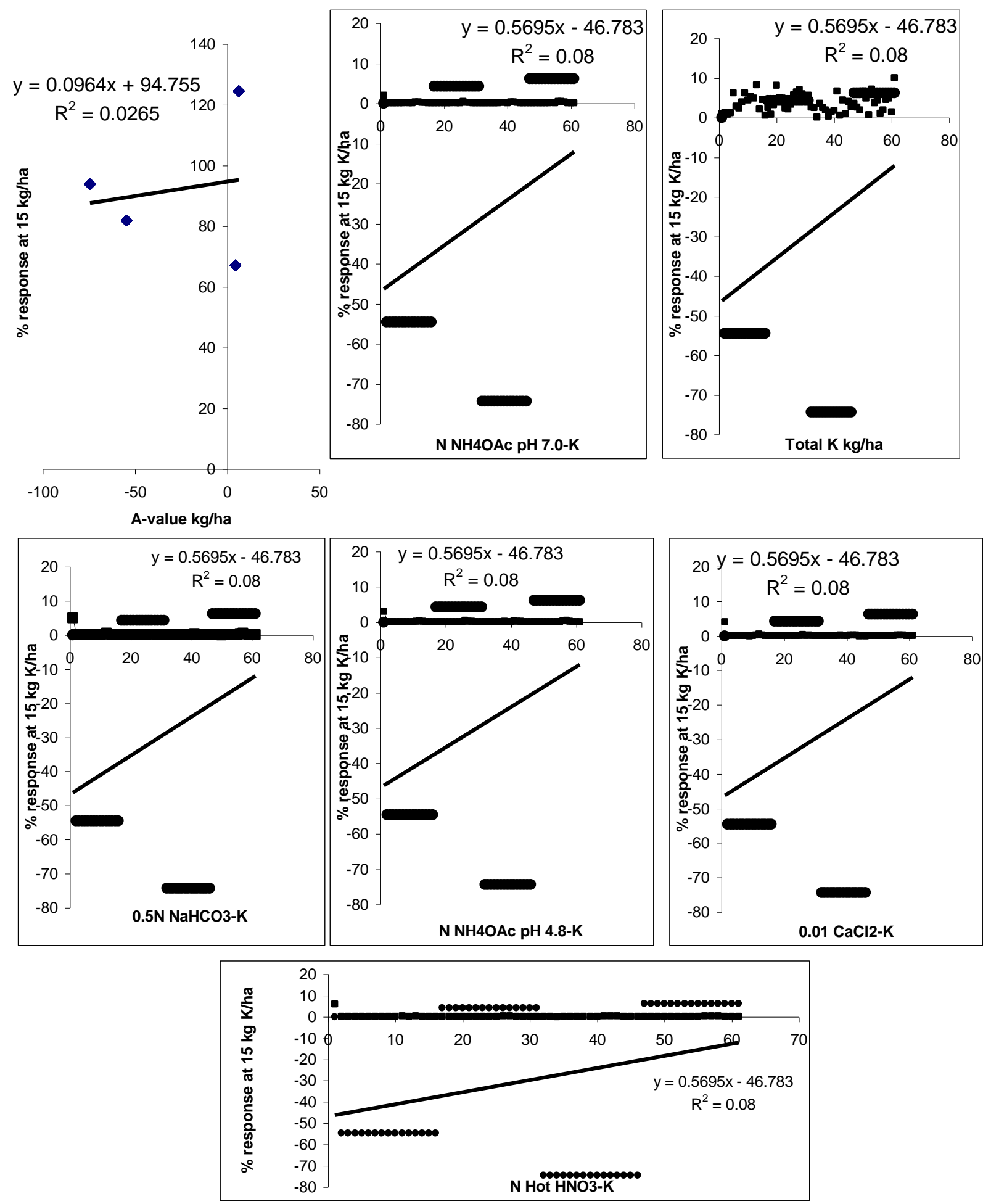
$2.05 \mathrm{~kg} \mathrm{~K}$ ha-1 $^{-1}$, hot $\mathrm{NHNO}_{3}-\mathrm{K}$ was below $2.91 \mathrm{~kg} \mathrm{~K}$ ha-1 $^{-1}$ and $\mathrm{N} \mathrm{NH}_{4} \mathrm{OAc} \mathrm{pH} 4.8-\mathrm{K}$ was below 2.46 $\mathrm{kg} \mathrm{K} \mathrm{ha-1.}^{-1}$.

The A-value and the data from all the laboratory methods correlated well with both the dry matter yield without potassium application and the percentage response, all significant at $0.5 \%$. Data from the $\mathrm{N} \mathrm{NH}_{4} \mathrm{OAc} \mathrm{pH} 7.0-\mathrm{K}$ method had the highest correlation coefficients with yield when potassium was not applied than did the data from the other methods. On the other hand, the correlation coefficient was the same for the five laboratory methods upon percentage response.

\section{DISCUSSION}

The soils of Nigerian Savanna are made up of low activity clays (LAC), thus the ability of the soils to retain nutrients and supply to crops is largely dependent on their organic matter contents (Abubakar et al., 2004). A decline in soil organic matter by two-thirds, such as happens when soils are continuously cropped represents a serious decrease in both the total reserve and availability of essential plant nutrients (Stangel, 1995).

In the Savanna, the rainfall and soil organic matters are relatively low and weathering results in the liberation, movement and accumulation of iron. The cation exchange capacity and leaching losses are low, so that even when exchangeable potassium is not appreciable, the percentage potassium saturation is relatively high and responses to potassium may not be expected. This proposition may partially explain the lack of response to potassium observed in both Otte and Malete soils.

Kwara State falls within the southern guinea savanna of Nigeria with a long term mean annual rainfall of $1,228.41 \mathrm{~mm}$. Population pressure has reduced the length of the fallow period and soil organic matter has consequently declined. With the decline in soil organic matter, the cation exchange-capacity would decline. Since, some potassium is lost by cropping with more intensive cultivation, the percentage potassium saturation remains low and responses to potassium may still be expected. This situation may partially account for the responses to potassium and the low levels of potassium extracted from the soils of Tsaragi and Omu Aran.

Although, the level of exchangeable $\mathrm{K}$ in Otte and Omu Aran soils would be regarded as being adequate for the immediate needs of plants (values being greater than $0.10 \mathrm{cmol} / \mathrm{kg}$ ), the low $\mathrm{K}^{+}$: $\mathrm{Ca}^{2+}$ or $\mathrm{K}^{+}: \mathrm{Ca}^{2+}+\mathrm{Mg}^{2+}$ poses serious problem for $\mathrm{K}^{+}$uptake in Otte soil. It was noted that the displacement of $\mathrm{K}^{+}$by $\mathrm{Ca}^{2+}$ was particularly important in the soils of New Zealand because of the selective adsorption of $\mathrm{Ca}^{2+}$ which resulted in leaching of $\mathrm{K}^{+}$(Wild, 1971). A high solution concentration of $\mathrm{Ca}^{2+}$ also led to reduced $\mathrm{K}^{+}$uptake by plants due to complementary ion effect occurring between $\mathrm{Ca}^{2+}$ and $\mathrm{K}^{+}$(Kirkman et al., 1994).

Explanation for the trend of responses to potassium in southern guinea savanna of Nigeria soils may also be found by evaluating the role of the parent rocks as a factor determining the characteristics of the soils. The soils of Tsaragi derived from sandstones are not easily weathered just like the other three soils derived from basement complex composed of acid crystalline metamorphic rocks that are resistant to weathering and have appreciable reserves of potassium in the primary minerals.

Bansal et al. (2002) reported that the divergent trend in respect of the non-exchangeable $\mathrm{K}$ distribution in different soils may be attributed to the variation in the fixation and release of $\mathrm{K}$ in 
soils as influenced by the cropping systems and fertilizer use pattern. Although the nonexchangeable $\mathrm{K}$ content variation in different soil groups and within a soil group may be due to differences in clay content and amount of K-bearing minerals like degraded-mica and vermiculites, soils dominated by kaolinitic clay mineral and iron oxides, like the red soil of Otte are most likely to have less non-exchangeable K (Sekhon et al., 1992). The fertilizer being used in Otte soil has failed to build-up or maintains the reserve $\mathrm{K}$ status in it (Ogunwale and Mohammed, 2006).

Furthermore, the influences of time and topography as genetic factors may be used to explain the lack of response to potassium in soils of Otte and Malete. Although, both soils were derived from basement complex just as the Omu Aran soil, their negative response could be attributed to the effect of time on the parent materials whose reserves of weatherable minerals may account for the lack of response to potassium.

In general, responses to potassium may occur in the sandy soils of the southern guinea savanna of Nigeria. No responses may be expected in the soils derived from basement complex, except in Omu Aran. These response trends may be explained using the genetic properties of the soils as influenced by rainfall and vegetation factors but the influence of parent rock appears to be dominant. In addition, the ratio of $\mathrm{K}^{+}$with respect to $\mathrm{Ca}^{2+}$ and $\mathrm{Mg}^{2+}$ in the soil solution is pertinent from the ion exchange point of view.

Of the laboratory methods used in assessing the potassium status of the soils, the neutral salts ( $\mathrm{N} \mathrm{NH}_{4} \mathrm{OAc} \mathrm{pH}$ 7.0) extraction methods permitted predictions of yields on soils receiving no potassium and would be suitable for the study of residual effects of manurial treatments and for indicating where responses would be expected. The five laboratory methods would be suitable for predicting the magnitude of responses when potassium is applied.

Hot $\mathrm{N} \mathrm{HNO}_{3}$ method would be most suitable for both kinds of predictions and is to be recommended as a rapid, precise and convenient soil-test method for assessing the availability of and crop response to potassium in the soils of Kwara State. The reason was that the data obtained were slightly higher than those for $\mathrm{N} \mathrm{NH}_{4} \mathrm{OAc}$ extractable potassium, the nitric acid extraction could therefore replace the usual $\mathrm{N} \mathrm{NH}_{4} \mathrm{OAc}$ method for the estimation of exchangeable potassium in these soils.

\section{CONCLUSION}

The genetic properties of Kwara State soils were reflected in the yield responses to potassium in greenhouse studies with sorghum and in the amounts of potassium extracted by laboratory methods. Responses were obtained in the acid sandy soils derived from the sandstones of Kwara state and a part of the basement complex of southern guinea savanna of Nigeria.

Potassium extracted with hot $\mathrm{NHNO}_{3}$ could be used to predict yields in soils receiving no potassium fertilizer as well as the magnitude of response to potassium application. The hot $N$ $\mathrm{HNO}_{3}$ method of potassium extraction has therefore been recommended as the most suitable soil-test method for evaluating potassium availability and predicting crop yields and responses to potassium on soils of Kwara state.

By the use of the method, the yield of unfertilized potted sorghum could be predicted with the equation $Y=0.0025 X+0.1701, r=0.0084$, significant at $0.5 \%$, and the percentage response 
$Y=0.5695 X+46.783, r=0.2828$ also significant at $0.5 \%$. When dry-matter yields were less than $9 \mathrm{~g} /$ pot significant responses were obtained; responses became significant when they were up to $9 \%$. Significant responses were obtained in soils tested below :70 kg ha-1 of A-value, $53.6 \mathrm{~kg} \mathrm{~K}$ ha-1 $^{-1}$ total $\mathrm{K}, 1.38 \mathrm{~kg} \mathrm{ha}^{-1} 0.01 \mathrm{M} \mathrm{CaCl}_{2}-\mathrm{K}, 2.05 \mathrm{~kg} \mathrm{ha}^{-1} 0.5 \mathrm{~N} \mathrm{NaHCO}_{3}-\mathrm{K}, 2.91 \mathrm{~kg} \mathrm{~K}^{-1}$ hot $\mathrm{N}$ $\mathrm{HNO}_{3}-\mathrm{K}$ and $2.46 \mathrm{~kg} \mathrm{~K}$ ha-1 $^{-1} \mathrm{NH}_{4} \mathrm{OAc} \mathrm{pH} 4.8-\mathrm{K}$.

\section{ACKNOWLEDGEMENTS}

This project work was carried out with personal funds. The authors greatly acknowledged the contributions of Professor J. A. Ogunwale of the University of llorin (retired) and the staff of the Soil Laboratory of the Lower Niger River Basin, Ilorin.

\section{REFERENCES}

Abubakar, S. Z., Jibrin, J. M. and Sulaiman, A. (2004). Effects of soil and water management practices on irrigation environment in Kano River Irrigation Project (KRIP), Nigeria. Proceedings of the $5^{\text {th }}$ International Conference and the $26^{\text {th }}$ Annual General Meeting of the Nigerian Institute of Engineers 26: 189 -197.

Bansal, S. K., Rao, C. S., Pasricha, N. S. and Imas, P. 2002. Potassium dynamics in major benchmark soil series of India under long-term cropping. Symposium No 54, Paper No 276 pp. $1-21,17^{\text {th }}$ WCSS, Thailand.

Cox, A. E., Joern, B. C., Brouder, S. M. and Gao, D. 1999. Plant-available potassium assessment with a modified sodium tetraphenylboron method. Soil Sci. Soc. Am. J. 63: 902-911.

Dean, L. A. 1954. Yield-of-phosphorus curves. Soil Sci. Soc. Am Proc. 18 : 462 - 466.

Ekpete, D. M. 1972. Predicting response to potassium for soils of eastern Nigeria. Geoderma 8: 177-189.

Fried, M. and Dean, L. A. 1952. A concept concerning the measurement of available soil nutrients. Soil Sci. 73: 263-271.

Isaac, R. A. and Kerber, J. D. 1971. Atomic absorption and flame photometry: Techniques and uses in soil, $\quad$ plant and water analysis. In L. M. Walsh (ed.). Instrumental methods for analysis of soil and plant tissue. Soil Sci. Soc. Am. Wisconsin, U. S. A.: Madison Inc.

Kirkman, J. H., Basker, A., Surapaneni, A. and MacGregor, A. N. 1994. Potassium in the soils of New Zealand - A review. New Zealand J. Agric. Res. 37: 207-227.

Krauss, A. 2003. Assessing soil potassium in view of contemporary crop production. Regional IPI-LIALUA Workshop on Balanced fertilization in contemporary plant production, Kaunas-Marijampol, Lithuania, September 30 - October 1, 2003.

Mohammed, K. O. 2006. Evaluation of soil extractants for available potassium by sorghum in selected soils in southern guinea savanna of Nigeria. J. Vocational and Technical Studies 6 (1): 124-132.

Mutschner, H. 1995. Measurement and assessment of soil potassium. IPI Research Topics No 4 (revised version). Switzerland: International Potash Institute Basel pp.102.

National Academy of Sciences-National Research Council. (1961). Statistical methods of research in economic and agronomic aspects of dertilizer response and use. Committee on economics of fertilizer use of the agricultural board. NAS. NRC. Publ. 918 NAS-NRC, Washington, DC.

Ogunwale, J. A. and Mohammed, K. O. 2006. Potassium quantity-intensity relations and uptake by Sorghum bicolor (L) Moench, in some selected soils of Kwara state, Nigeria. J. Arid Agric. 16: 121-127. 
Ogunwale, J. A., Olaniyan, J. O. and Aduloju, M. O. 2002. Morphological, physico-chemical and clay mineralogical properties of soils overlying basement complex rocks in llorin East, Nigeria. Moor J. Agric. Res. 3 (2): 147-154.

Rehm, G., Randall, G., Lamb, J. and Eliason, R. 2006. Fertilizing corn in Minnesota.Univ. of Minnesota Ext. Publ. FO-03790 Rev. 2006. Available at http: // www. Extension. Umn. Edu/ distribution/ cropsystems/ DC 3790. html (verified 29th May, 2008).

Samadi, A. 2006. Potassium exchange isotherms as a plant availability index in selected calcareous soils of Western Azarbaijan Province, Iran. Turk. J. Afric. 30: 21-222.

Sekhon, G. S., Brar, M. S. and Subba Rao, A. 1992. Potassium in some benchmark soils of India. PRIC Special Prob. No 3: 1-82.

Stanford, G. 1973. Rationale for optimum nitrogen fertilization in corn production. J. Environ. Qual. 2: $159-166$.

Stangel, P. J. 1995. Nutrient cycling and its importance in sustaining crop-livestock systems in subSaharan Africa: An overview. In: Powell, J. M., Fernandez-Rueria, S., Williams, T. O. and Renard, C. (eds.). Livestock and sustainable nutrient cycling in mixed farming systems of subSaharan Africa. Vol II.Technical papers proceedings of ILCA Conference, Addis-Ababa, Ethiopia pp. 37-62.

Udo, E. J. and Ogunwale, J. A. 1978. Forms and distribution of potassium in selected Nigerian soils. Niger. J. Sci. 12 (1 and 2): 215-232.

Vanotti, M. B. and Bundy, L. G. 1994a. An alternative rationale for corn N fertilizer recommendations. J. Prod. Agric. 7: 243-249.

Vanotti, M. B. and Bundy, L. G. 1994b. Corn nitrogen recommendations based on yield response data. J. Prod. Agric. 7: 249-256.

Wild, A. A. 1971. The potassium status of soils in the savanna zone of Nigeria. Expl. Agric. 7: 257-270. 